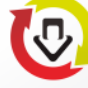

Check for updates
Article Type: Research Paper

\section{Factors Affecting Financial Condition of Local Government in Indonesia}

\author{
Irwan Taufiq Ritonga ${ }^{1 *}$, Colin Clark², Guneratne Wickremasinghe ${ }^{2}$
}

ABSTRACT: This study empirically examines factors affecting the financial conditions of local governments (LGs) in Indonesia. This study utilizes a quantitative approach to achieve the research objective. The theory used to achieve the objective is the theory of demand and supply. To test the hypothesis, this study employs multiple regression analysis. The results show that four of seven factors identified in previous literature (namely, financial efficiency, cost of services and goods, population, and revenue-base) significantly influence the financial conditions of LGs, whereas the remaining three factors (namely population density, age profile of the community, and wealth of community) do not. Based on the law of supply, technology is known as one factor that influences the number of products and services produced by an organization. This study does not examine the impact of this variable on financial conditions of LGs because there was no data available about the level of technology utilization in LGs in Indonesia when this study was undertaken. These findings have implications for central government, LG executives and legislators in Indonesia in formulating policies pertaining to the financial conditions of LGs, for example, policy for decentralization funds. Such policies can enable quality decision-making to improve their financial conditions.

KEYWORDS: local government; financial condition; law of supply and demand

\section{Introduction}

Indonesia is a unitary state which implements a decentralized governance system by granting autonomy to local governments. Local government (LG) autonomy is the delegation of all authorities and submission of all the central government's affairs, except the affairs of foreign policy, defence, security, judicial, monetary and national fiscal, and religion to LGs within the framework of democracy and national development by involving local people's aspirations and participation (Local Government Amendment Act, 2004). Thus, the development in a region will be based on its people's economic and political aspirations.

An important function of LGs is to manage their finances, which is called fiscal decentralization. Fiscal decentralization is a process of distribution of 


\section{Ritonga, Clark \& Wickremasinghe \\ Factors Affecting Financial Condition of Local Government in Indonesia}

funds from the higher levels of government to the lower levels of government to support the delegation of authority and submission of some of the higher level government's affairs to the lower level governments (Fiscal Balance between Central and Local Government Act, 2004). Fiscal decentralization is a logical consequence of the implementation of regional autonomy concerning the concept of money follows functions ${ }^{1}$, which means that the transfer or delegation of central government authorities must be accompanied by the allocation of funds needed to exercise these powers. Fiscal Balance between Central and Local Government Act (2004) authorizes LGs to obtain financial resources in the form of assurance from the central government (i.e. decentralization fund) in accordance with the affairs of the central government handed over to LGs, collect and utilize taxes and levies, obtain the results of national resources in their area, and manage regional assets and obtain sources of legitimate income and sources of financing.

In the framework of LG autonomy, each LG is granted rights to design their own policies to achieve national objectives as long as there is congruence with the central government's strategic plan. The central government only provides principles of managing local finance to LGs rather than detailed rules it provided previously. As a result, each LG has its own programs and activities based on its people's perceptions both economically and politically. The implementation of those programs and activities is financed through the LG budget. Because each LG has different programs and activities, each LG will have a different budget allocation. As a result, the financial condition of each LG would vary. For example, there were 124 out of 491 LGs in Indonesia experiencing financial problems such as paying their employees' salaries in the fiscal year 2011 (Harian Surya, 2 August 2011, p.1). In the Central Java Province only, 11 out of 35 LGs experienced such problems (Harian Kedaulatan Rakyat, 16 June 2011, p.1). Such variation creates the need for LG stakeholders to know what factors determine the variation in the financial conditions of LGs.

There is little empirical evidence about factors affecting the financial condition of LGs in other countries (Jones and Walker, 2007; Dennis, 2004) including those in Indonesia Unlike the business sector in which financial assessments of firms are clearly defined research assessing the financial conditions of LGs is relatively new because such research just started in the 1980s (Kloha et al., 2005a). This can be contrasted with the business sector where such research commenced 20 years earlier. In the business sector, Beaver (1966) and Altman (1968) established a seminal model to assess the financial conditions of a firm. This situation has created difficulties for LG executives and legislators in making effective policy responses whenever the financial conditions of LG worsen. In addition, among the limited attempts to explain the LG financial condition, unfortunately, prior research do not indicate what theory the researchers used to explain the variation of LG financial condition (see Casal and Gomez,2011; Carmeli and Cohen, 2001; Jones and Walker, 2007; Honadle et al., 2004; Zafra-Gomez et al., 2009).

${ }^{1}$ Concept of money follows functions referring to the budget allocation which is based on the functions of each level of local government entrusted by the law to it in order to avoid overlapping of functions and activities performed by each level of local government (State Finance Act 17, 2003). 
Rubinfeld (2000) explain that causation cannot be obtained solely by analyzing data. A researcher must conclude that the existence of cause and effect is based on a theory that explains the causal relationship between the two factors under study. Moreover, when a proper theory has been recognized, a cause and effect relationship cannot be derived directly because researcher also has to seek empirical evidence proving that there are a cause and effect relationship (Rubinfeld, 2000). In addition, the previous research has not analyzed extensively the factors influencing local government financial condition, how these factors influence the financial condition and why one local government is healthier than another.

This study attempts to remedy the weaknesses of previous studies explained above. The framework used in this study to answer the research question as to what factors affect the financial condition of local government are supply and demand framework related to public finance. To the researcher's knowledge, there is no prior research using the framework of supply and demand to explain the variation in local government financial condition.

Based on the research problem stated above, this study raises the following issue: what factors affect the financial condition of LG? The framework used to answer the research questions is demand and supply framework. As applied to this study, the framework holds that it is expected that the independent variables (population; age profile; population density; wealth of community; financial efficiency; costs of production of services and goods; and revenue-base) influence or explain the dependent variable (the financial condition of LG).

This study offers contributions for central government, LG executives and legislators in Indonesia in formulating policies pertaining to the financial conditions of LGs, for example, policy for decentralization funds. Such policies can enable quality decisionmaking in order to improve their financial conditions. In addition, this study attempts to remedy the main weakness of previous studies, which is do not indicate what theory the researchers used to explain the variation of LG financial condition. Furthermore, this study represents the first attempt to assess the financial conditions of LGs in Indonesia.

\section{Literature Review and Hypotheses Development}

\section{Definition of Local Government Financial Condition}

Various definitions of LG financial condition have been developed by researchers and institutions (seeKloha et al., 2005a; Kloha et al., 2005b; Jones and Walker, 2007; Hendrick, 2004; CICA, 1997; Groves et al., 1981; Berne and Schramm, 1986; Nollenberger et al., 2003; Kamnikar et al., 2006;Wang et al., 2007; Rivenbark et al., 2009; Rivenbark et al., 2010; Rivenbark and Roenigk, 2011). This study defines the financial condition of $L G$ as the financial ability of $L G$ to fulfill its obligations (short-term obligations, long-term obligations, operational obligations, and obligations to provide services to the public), to anticipate the unexpected events, and to execute financial 
rights efficiently and effectively. A detailed explanation of how such a definition is conceptualized is provided in Ritonga et al. (2012b).

Based on the definition stated above, there are six dimensions forming the financial condition of LG (Ritonga et al., 2012a; 2012b). The dimensions are: (1) the ability to meet short-term obligations, hereafter called short-term solvency; (2) the ability to meet operational obligations, hereafter called budgetary solvency; (3) the ability to meet long-term obligations, hereafter called long-term solvency; (4) the ability to overcome unexpected events in the future, hereafter called financial flexibility; (5) the ability to execute financial rights in an effective and efficient manner, hereafter called financial independence; and (6) the ability to provide services to the community, hereafter called service-level solvency.

\section{Factors Affecting Financial Condition of Local Government}

Researchers, although not many, have attempted to explain factors affecting the financial condition of LG. Berne and Schramm (1986) argued that the major determinants of the financial condition of LG in United States are: (1) community tastes and needs; (2) the local conditions affecting production and distribution of public goods and services; (3) the costs of labour, capital, and other productive resources; (4) the wealth of the community; (5) the political and governmental structure in the locality and surrounding area; (6) federal and state policies affecting local resources, constraints, and responsibilities ; and (7) government financial policies and practices. Ladd (1992) reported a U-shaped relationship between local government expenditures and population density. Clark (1994) offers several factors that cause financial strain: population and economic base; political leadership; unions; ethnic groups and disadvantage; and grant legal structure. Nollenberger et al. (2003) argued that there are three factors affecting the financial condition of LG, namely environmental factors, organizational factors, and financial factors. Honadle et al. (2004) provided selected examples of the kinds of factors affecting financial health: the frequency and severity of occurrence of natural disasters in a local government area; condition of the national economy; composition of the local economic base; tax bases of a local government; applicable tax rates in a local government; population changes; labour costs; pressure from the voting public for public services; and what to finance and how to finance projects and programs. Rubin's 1982 and Pammer's 1990 studies (Kloha 2005a, 2005b) stated that LG distress is caused by four factors, namely population and job market shifts, governmental growth, interest group demands, and poor management. Wang et al. (2007) state that financial conditions are associated with socioeconomic variables, such as population, personal income per capita, gross state product per capita, population growth rate, percentage change in employment, percentage change in personal income, economic momentum index, and momentum rank change. Supporting Wang et al.'s (2007) work, In Spain, Zafra-Gómez et al. (2009) in their study assumed that the socioeconomic factors affect the financial condition. In Australia, Jones and Walker (2007) found that population, size of municipalities, road maintenance costs, carrying values of infrastructure assets, revenue-generating capacity and the number of full-time staff are related with financial distress. Casal and Gomez (2011) found that 
population size and geographic location of local government influence some dimensions of the financial condition of municipalities in Spain.

In general, the research mentioned above does not state what theories were used to determine the factors affecting the financial condition of local government. According to Rubinfeld (2000), causation cannot be obtained solely by analyzing data. A researcher must conclude the existence of cause and effect based on a theory that explains the causal relationship between the two factors under study. Moreover, when a proper theory has been recognized, a cause and effect relationship cannot be derived directly, because researchers also have to seek empirical evidence proving that there is a cause and effect relationship (Rubinfeld, 2000).

Also, the previous research has not analyzed extensively the factors influencing local government financial condition, how these factors influence the financial condition and why one local government is healthier than another. Carmeli (2003) states that researchers know little about the dynamics that create fiscal and financial crises; researchers have limited knowledge about sources of fiscal and financial crises between local government, and researchers are still far from a complete theoretical framework supported by valid empirical evidence to explain why local government faces financial crises. Why such situations occur? Carmeli (2003) argues that those situations are due to the complexity of the factors driving the financial condition of local government. There are no easy or immediate ways, at least not in the near future, to understand the variation of local government financial condition. Accumulative knowledge is the only way to ensure that researchers will understand the phenomenon properly (Carmeli, 2003).

\section{Demand Theory and Supply Framework}

Deacon (1978) argued that demand theory could be applied to public sector spending because public budgets are allocated among services in much the same manner that households allocate income to private commodities. Ohls and Wales (1972) also used demand theory and supply theory to explain differences in per capita expenditures across countries.

In the economic context, demand for services and products provided by a firm depends on income, price, several buyers, prices of other products, quality, tastes and preferences, and expectation about the future (Mankiw et al., 1999). In the LG environment context, demand for services and goods provided by an LG depends on population, community needs and tastes, and income per capita of the community (Berne and Schramm, 1986; Deacon, 1978; Hyman, 1990; Ohls and Wales, 1972).

Supply is defined as the quantity of a product that a producer is willing and able to supply onto the market at a given price in a given period. The basic law of supply is that as the price of a commodity rises, producers expand their supply onto the market. In the economic context, factors affecting the supply of services and goods are production costs, the technology used in production, the price of related services and goods, firm's 


\section{Ritonga, Clark \& Wickremasinghe \\ Factors Affecting Financial Condition of Local Government in Indonesia}

expectation about future prices, and several suppliers (Mankiw et al., 1999). Among these factors, the relevant factor for the LG environment is the cost of services and goods and the cost of delivering services and goods (Hyman, 1990; Ohls and Wales 1972). These costs are related to cost of capital, labor, and other resources, population, and population density.

\section{Association between LG Financial Condition and Population}

Hyman (1990) argued that population affects per capita LG expenditure both on the demand and supply sides. As the population increases, more public facilities must be provided by LG to the public. Furthermore, more social problems also occur if the number of people increases. This condition will cause the demand curve of LG-provided services and goods ${ }^{2}$ to shift to the right. As a result, total LG expenditure will increase. On the other hand, the larger population will lead to the achievement of economies of scale. These conditions will shift the supply curve of LG-provided services and goods downward and to the right. In turn, cost per unit of services and goods will decrease. Assuming that services and goods provided by LG are normal goods ${ }^{3}$ and the nature of demand of services and goods is elastic ${ }^{4}$ (Hyman, 1990), the community will switch to use more of the services and goods provided by LGs. As a result, LG expenditure per capita will increase because the effect of demand side (i.e., increasing in the number of services and goods demanded) is larger than the effect of the supply side (i.e., decrease in the cost per unit of services and goods). Thus, the simultaneous shifts of demand and supply curves will cause the total expenditure per capita of LG to increase. The increase in total expenditures per capita will in effect decrease budget surplus or increase the budget deficit. As a result, the dimension of the budgetary solvency will decrease. Holding other factors constant, this condition will deteriorate the LG financial condition.

Pammer (1990), Rubin (1982), Wang et al. (2007) and Jones and Walker (2007)found that size of the population is negatively associated with financial condition index in local councils. Wang et al. (2007) argued that larger populations might demand greater public spending which can lead to deteriorating financial conditions if additional revenues are not generated proportionally to fund the increased service demand. Based on the explanation above, this study formulates the following hypothesis for the relationship between population and the financial condition of local government.

$\boldsymbol{H}_{1}$ : Population is negatively associated with the financial condition of local government.

\section{Association between LG Financial Condition and Age Profile of Community}

The age profile of the community refers to the composition of the population of working groups and non-working groups. The age profile of the community will affect the taste

\footnotetext{
2 Goods discussed in developing hypotheses in this study are both private and public goods provided by local government which have character of normal goods.

${ }^{3}$ Normal good is a good for which, other things being equal, an increase in income leads to increase in demand (Mankiw, 2007, p.68).

${ }^{4}$ Demand for a good is elastic when quantity demanded change significantly in response to changes in prices.
} 


\section{Ritonga, Clark \& Wickremasinghe \\ Factors Affecting Financial Condition of Local Government in Indonesia}

and needs for services and goods provided by LGs (Berne and Schramm, 1988). The age profile affects LG-provided services and goods on the demand side. Worker groups (people aged between 18 and 60 years old) have a sense and need for services and goods that are different from the needs of the non-working community groups (which consist of people under the age of 18 years and over 60 years). For example, nonworking community groups need more certain type of facilities such as schools, parks and recreation, and nursing homes that are not needed by a group of workers. This condition will result in additional expenditures of LGs to provide these facilities. As a result, the demand curve of services and goods will shift to the right. Thus, LGs that have a higher percentage composition of the community with age profile of non-working groups will face higher pressure on demand spending than LGs that have a community with a lower percentage composition of the age profile of non-working groups. In turn, LG total expenditure will increase, and per capita expenditure will increase, as well. The increase in total expenditures per capita will in effect decrease budget surplus or increase the budget deficit. As a result, the dimension of the budgetary solvency will decrease. Holding other factors constant, this condition will deteriorate the financial condition.

Jin and Zhang (2001) and Zafra-Gomez et al. (2009c) found that an increase in the number of non-working groups of community results in an increase in local government expenditure, which leads to the deterioration of the financial condition. Based on the above explanation, this study formulates the following hypothesis for the relationship between the age profile and the financial condition of local government.

$\mathrm{H}_{2}$ : Community age profile is negatively associated with the financial condition of local government.

\section{Association between LG Financial Condition and Wealth of Community}

A wealth of the community affects the LG-provided services and goods on the demand side. It is believed that LG-provided services and goods are normal goods (Hyman, 1990). Therefore, the more prosperous the society, the greater the number of services and goods that society wants. As a result, LG total expenditures will increase. Also, not only does the quantity increase, but also the quality of the desired LG provided-services and goods will be higher. For example, in the health care sector, the more prosperous society will ask for better services such as specialist physician services (rather than general doctor services) and branded drugs (rather than generic drugs) and the like. This situation will shift the demand curve of services and goods to the right. In turn, LG total expenditure will increase, and the per capita expenditure will increase, as well. The increase in total expenditures per capita will in effect decrease budget surplus or increase the budget deficit. As a result, the dimension of the budgetary solvency will decrease. Holding other factors constant, this condition will deteriorate the LG financial condition.

Borcherding (1985) and Ohls and Wales (1972) found that a community with relatively high wealth is likely to buy relatively large amounts of both state-produced and private 


\section{Ritonga, Clark \& Wickremasinghe \\ Factors Affecting Financial Condition of Local Government in Indonesia}

goods, and hence one would expect the demand curve to shift to the right with an increase in income. As a result, LG total expenditure will increase. This situation worsens LG financial condition. Douglas and Gaddie (2002) and Wolkoff (1987) also found a positive relationship between state general fund expenditures and per capita personal income. In their study, Wang et al. (2007) found that the relationship between financial condition index and personal income per capita is negative. They argued that individuals with higher personal incomes might require increased public spending in certain areas tailored to higher income populations which may eventually worsen the LG financial condition. Based on the explanation above, this study formulates the following hypothesis for the relationship between community wealth and the financial condition of local government.

$\boldsymbol{H}_{3}$ : Level of the wealth of community is negatively associated with the financial condition of local government.

\section{Association between LG Financial Condition and Population Density}

Population density affects LG-provided services and goods through the supply sides. The increasing density of population (i.e., the closer the distance among households) is believed to reduce the cost per unit of goods and services produced by LG (Downing, 1973). Also, Hyman (1990) argued that the average cost per unit is analog to its price per unit. The lower cost per unit leads an LG to supply more goods and services to the community. This situation will shift the supply curve of services and goods to the right. The increase in goods and services supplied to the community will result in improved service-level solvency. Holding other factors constant, the financial condition of LG will improve.

Borcherding and Deacon (1972) and Downing (1973) found that population density is inversely related to per capita expenditure. In addition, Ladd (1992) cited in Carmeli (2008) found that as population density increases, local government costs decrease. Furthermore, Carmeli (2008) argued that smaller local authorities are unable to reach optimal levels of economic efficiency because of their limited resources and complex challenge. Carmeli (2008) also found that larger local authorities enjoy better fiscal health than smaller local authorities. Based on the above explanation, this study formulates the following hypothesis for the relationship between population density and the financial condition of local government.

$\boldsymbol{H}_{4}$ : Population density is positively associated with the financial condition of local government.

\section{Association between LG Financial Condition and Revenue-base}

Revenue-base refers to the resources from which an LG generates its revenues. Revenue-base affects LG-provided services and goods on the supply side. An LG with strong revenue-base could supply more revenues to LG. As a result, LG can provide more goods and services to the community. Therefore, the supply curve of services and goods 
Ritonga, Clark \& Wickremasinghe

Factors Affecting Financial Condition of Local Government in Indonesia

will shift to the right. The increase in goods and services supplied to the community will result in improved service-level solvency. Holding other factors constant, the financial condition of LG will improve. Carmeli (2008), Pammer (1990), Rubin (1982) and Wang et al. (2007) found that there is a negative association between local government revenue base and level of local government financial distress. Based on the above explanation, this study formulates the following hypothesis for the relationship between the revenue base and the financial condition of local government.

$\boldsymbol{H}_{5}$ : Local government revenue-base is positively associated with the financial condition of local government.

\section{Association between LG Financial Condition and Financial Efficiency}

Financial efficiency refers to efficient practices of financial management undertaken by LGs. Examples of efficient practices include the use of technology; and the use of resources (i.e., personnel and equipment) not in excessively. Financial efficiency affects LG-provided services and goods on the supply side. Good financial efficiency practices will lower the cost per unit of services and goods. As a result, LGs can provide more goods and services to the community. Therefore, the supply curve will shift to the right. The increase in goods and services supplied to the community will result in improved service-level solvency. Holding other factors constant, the financial condition of LG will improve.

Pammer's 1990 study (Kloha, 2005, p.314) argued that poor management causes financial stress of local governments. In addition, Beck (1982) argued that bureaucratic inefficiency is a contributor to fiscal stress as in the case of Cleveland. Furthermore, Jin and Zhang (2011) found that poor management has a statistically negative effect on local government financial condition. Based on the above explanation, this study formulates the following hypothesis for the relationship between financial efficiency and the financial condition of local government.

$\boldsymbol{H}_{6}$ : Local government financial efficiency is positively associated with the financial condition of local government.

\section{Association between LG Financial Condition and Cost of Services and Products}

To produce goods and services, LG uses relevant resources such as labor, raw materials and overhead. Input prices of relevant resources affect LG-provided services on the supply side. In general, the lower the prices of relevant resources, the lower the average price per unit of the services and goods will be. In turn, more goods and services can be supplied by LG to the community. Therefore, LGs with lower prices of relevant resources will be able to supply more goods and services to the people in the community. As a result, the supply curve will shift to the right. The increase in goods and services supplied to the community will result in improved service-level solvency. Holding other factors constant, LG's financial condition will be better. 
LGs with higher prices of relevant resources will supply fewer goods and services. If such an LG supplies the goods and services in the same amount as LGs which have lower input price, then this LG will most likely have to take out loans from the third parties (i.e., banks, other governments, or the central government). As a result, LG will have a weaker dimension of short-term solvency, budgetary solvency, long-term solvency, and financial flexibility. In turn, LG's financial condition will worsen.

Baumol (1967) and Bradford et al. (1969) found that wages and salaries of local government employees are the major determinants of costs of services and goods provided by local governments, and Beck (1982) found that exorbitant municipal wages and welfare expenditure are a contributor to fiscal stress. Based on the above explanation, this study formulates the following hypothesis for the relationship between the cost of services and products and the financial condition of local government.

$\mathrm{H}_{7}$ : Cost of production of services and products is negatively associated with the financial condition of local government.

\section{Research Method}

\section{Data and Sample}

This study used secondary data which were socioeconomic data and audited LG financial statements for the fiscal year of 2010. The reason to use the fiscal year 2010 is that in that year the Central Bureau of Statistics conducted a census of population in Indonesia. Thus, reliable data on population size, population density, and age profile of the population, three factors that are examined, are available for this year.

To obtain reliable data, we took the data directly from the original sources. We obtained the data for LG financial statements, which are publicly available, from the Supreme Audit Board. To increase data reliability, we used the financial statements which had an unqualified opinion or qualified opinion. We did not include financial statements which had a disclaimer of opinion or an adverse opinion because such financial statements would reduce the reliability of data. We obtained the socioeconomic data of population, population density, regional minimum wage, gross domestic product, jurisdiction area, number of people who live above the poverty line, and age profile of population from the Central Bureau of Statistics, the Ministry of Home Affairs, and the Ministry of Finance.

Because this study utilized purposive sampling to choose the elements in the population as sample objects, the number of samples was adjusted to the criteria set by the researcher. The rationale for the sample size was based on the arguments of Sekaran and Bougie (2010) and Roscoe (1975). Sekaran and Bougie (2010) argue that too large or too small a sample size is detrimental to a research project. Also, Roscoe (1975) argues that a sample size larger than 30 and less than 500 is appropriate for most research and if a research divides samples into sub-samples, the minimum number of each sub- 
sample is 30 . To achieve homogeneity so that comparability is maximized, this study uses financial statements of district LGs in Java Island as the sample. District LGs in Java Island are relatively homogenous about the environment, socioeconomic factors, culture, and infrastructure. Besides that, the number of LGs in Java Island (83 district LGs) was considered adequate from a statistical perspective.

\section{Operational Definition of Variables}

Independent Variables

The operational definitions of independent variables in this study are as follows:

\section{a. Population size}

Population size refers to the number of citizens who live in the territory of a local government in a given time. This study utilized population size from the 2010 census.

\section{b. The age profile of the community}

Nollenberger et al. (2003) argue that the age profile is a surrogate for people's desires and tastes. Age profile refers to the number of people in a community who need particular services and products provided by the local government. This variable is measured by using a ratio of the population under the age of 18 years and the age of over 60 years divided by the total population. The formula is: Age profile $=$ (population under 18 years + population over 60 years) / Total population.

\section{c. Wealth of community}

The wealth of the community refers to the level of prosperity of a society. There have been many indicators developed by previous researchers to measure it. The indicators include median family income, percentage of families in the community with income greater than a certain level, assessed valuation per capita and mean wage or salary income of individuals (Hyman, 1990). Weicher (1970) uses other variables as indicators for community wealth: median value of dwelling units, proportion of households with incomes lower than the poverty line, proportion of city employment in manufacturing, per capita retail sales, employment rates and percentage of non-white population. This study uses a ratio of the number of people who live above the poverty line to the population as a measure of community wealth.

\section{d. Population density}

Population density refers to the number of people living in a square kilometer. It is a measure of the dispersion of the residential population within the legal boundaries of a community (Hyman, 1990). This variable is measured by the ratio of population size divided by jurisdiction area in square kilometers in a particular period.

\section{e. Cost of services and goods}

Cost of services and goods refers to the prices of relevant resources to produce services and goods provided by the local government. The relevant resources consist of labor, direct materials, capital, and land. The cost of wage and salaries is the major component of the costs of producing services and goods by local government (Bradford et al., 1969; 


\section{Ritonga, Clark \& Wickremasinghe \\ Factors Affecting Financial Condition of Local Government in Indonesia}

Hyman 1990). Therefore, the variable of cost of services and goods provided by local government is measured by using the minimum of regional wage.

\section{f. Local government financial efficiency}

Local government financial efficiency refers to the level of efficiency of local government in delivering services and goods to the community. This variable is measured by using a ratio of total expenditures to employee expenditures. The reason for using the ratio is based on arguments from Baumol (1967) and Beck (1982). Baumol (1967) argues that, unlike in the business sector in which increases in wage levels are offset by increases in productivity, in local government, such a condition does not occur. Beck (1982) found that very high public servant salary and benefit expenditures ${ }^{5}$ contribute to financial strain.

In addition, in the case of Indonesian local government, it is believed that the number of employees is too high. As a result, lots of light work is done by more than one employee (Harian Jawa Pos, 21 December 2011, p.1). This condition leads to inappropriate composition of employee expenditures and impairs the efficiency of public services provided by the local government. The Minister of Home Affairs, Gamawan Fauzi, states that the composition of employee expenditures to total expenditures for the financial year 2011 was more than $50 \%$ in 294 local governments in Indonesia (Harian Kompas, 25 August 2011, p.1). This means that the amount of employee expenditures is greater than the amount of capital and maintenance expenditures for preserving public services. Based on this condition, on 24 August 2011, three ministers (the Minister of Finance, Minister of Home Affairs and Minister of Administrative and Bureaucratic Reform) signed a joint decree providing a moratorium on employee recruitment.

\section{g. The revenue base of local government}

The revenue base refers to the resources from which a local government generates its revenues. Berne and Schramm (1986) state that the performance of an economy is reflected in the magnitude and value of the goods and services it produces. The variable of revenue base is measured by using the gross domestic product (GDP) at constant prices. GDP at constant prices is the total market value of all the goods and services produced within the borders of a local government during a specified period by eliminating the effect of inflation. Therefore GDP at a constant price is in line with the concept of the revenue base.

\section{Dependent Variable}

This study adopts Ritonga et al. (2012) model to measure local government financial conditions because their model is reliable, valid and practical. The model satisfies the criteria of theoretically robust, possess the qualities of measurement validity and reliability, assess local government financial condition as a whole, provide predictive ability, distinguish among the local governments evaluated; utilize data that are available to the public, uniform and collected regularly; and practical. The operational

\footnotetext{
5 In the context of Indonesia, benefit expenditures include allowances for renting houses, allowances for communication, allowances for utilities, allowances for insurance.
} 
definitions of dependent variables in this study are as follows. Table 1 provides the indicators used by Ritonga et al. (2012) to measure each of the six dimensions of the LG financial condition.

Table 1 Dimensions and Indicators of the Financial Condition

\begin{tabular}{|c|c|}
\hline Dimension & Indicators \\
\hline Short-Term & Ratio $A=$ (Cash and Cash Equivalent + Short term Investment) : Current \\
\hline \multirow{5}{*}{ Solvency } & Liabilities \\
\hline & Ratio $B=$ (Cash and Cash Equivalent + Short term Investment + Account \\
\hline & Receivables) : Current \\
\hline & Liabilities \\
\hline & Ratio $C=$ Currents Assets : Current Liabilities \\
\hline Budgetary & Ratio A = (Total Revenues - Special Allocation Fund Revenue) : (Total \\
\hline \multirow[t]{7}{*}{ Solvency } & Expenditures - Capital \\
\hline & Expenditure) \\
\hline & Ratio $B=($ Total Revenues - Special Allocation Fund Revenue) : Operational \\
\hline & Expenditure \\
\hline & Ratio C = (Total Revenues - Special Allocation Fund Revenue) : Employee \\
\hline & Expenditure \\
\hline & Ratio $D=$ Total Revenues : Total Expenditure \\
\hline Long-Term & Ratio A = Long Term Liabilities: Total Assets \\
\hline \multirow[t]{2}{*}{ Solvency } & Ratio B = Long Term Liabilities: Investment Equities \\
\hline & Ratio $\mathrm{C}=$ Investment Equities: Total Assets \\
\hline Service-Level & Ratio A = Total Equities : Population \\
\hline \multirow[t]{2}{*}{ Solvency } & Ratio B = Total Assets : Population \\
\hline & Ratio $\mathrm{C}=$ Total Expenditures : Population \\
\hline Financial & Ratio A = (Total Revenues - Special Allocation Fund Revenue - Employee \\
\hline \multirow[t]{9}{*}{ Flexibility } & Expenditures) : \\
\hline & (Repayments of Loan Principal + Interest Expenditures) \\
\hline & Ratio B = (Total Revenues - Special Allocation Fund Revenue - Employee \\
\hline & Expenditures) : \\
\hline & Total Liabilities \\
\hline & Ratio C = (Total Revenues - Special Allocation Fund Revenue - Employee \\
\hline & Expenditures) : \\
\hline & Long Term Liabilities \\
\hline & $\begin{array}{l}\text { Ratio D = (Total Revenues - Special Allocation Fund Revenue) : Total } \\
\text { Liabilities }\end{array}$ \\
\hline Financial & Ratio A = Total Own Revenues $:$ Total Revenues \\
\hline Independence & Ratio B = Total Own Revenues : Total Expenditures \\
\hline
\end{tabular}

\section{Research Procedures}

Procedure 1: Build Composite Index of LG Financial Condition as Dependent Variable

The first step is to calculate all indicators forming the dimensions of financial condition. The second step is to develop an indicator index. The index of each indicator is calculated by using the formula given below: 


\section{Indicator Index = (Actual Value - Minimum Value) : (Maximum Value - Minimum Value)}

The third step is to determine the dimension index by using the arithmetic mean ${ }^{6}$ for which the formula is as follows:

Dimension Index $=\left(I_{\text {Indicator-1 }}+I_{\text {Indicator-2 }}+\ldots+I_{\text {Indicator-n }}\right): n$

Where:

$\mathrm{n}=$ number of indicators forming the dimension

Dimension index $=$ the average of the indicator indexes that compose it

After determining the dimension index, the fourth step is to develop a Composite Financial Condition Index (FCl). The formula to create this index is as follows:

$\mathrm{FCl}=\mathrm{w}_{1} * \mathrm{DI}_{1}+\mathrm{w}_{2} * \mathrm{DI}_{2}+\ldots \ldots+\mathrm{w}_{\mathrm{n}} * \mathrm{DI}_{\mathrm{n}}$

Where:

$\mathrm{FCl}=$ Financial Condition Index

$\mathrm{w}=$ weight of dimension index

$\mathrm{DI}=$ dimension index

$\mathrm{n}=$ number of dimension.

The indicator index, dimension index, and composite index are the result of the transformation of the variable value into a value between 0 and 1 . A value of 0 indicates the minimum value and a value of 1 indicates the maximum value for the index; 1 meaning a perfect score of financial condition. In calculating the financial condition index, it is assumed that the weight of each dimension is equal, although the authors believe that the weight of each dimension should be different. Ritonga et al. (2012a) provided a detailed discussion about how to develop the LG financial condition index.

Procedure 2: Analysing Factors Affecting the Financial Conditions

We used multiple regression model to test the hypotheses. The multiple regression model is:

$\mathrm{FCl}=\alpha+\beta_{1} \mathrm{Pop}+\beta_{2} \mathrm{AP}+\beta_{3} \mathrm{WC}+\beta_{4} \mathrm{PD}+\beta_{5} \mathrm{CSG}+\beta_{6} \mathrm{FE}+\beta_{7} \mathrm{RB}+\varepsilon$

where:

$\mathrm{FCl}=$ fiscal condition index

$\alpha=$ overall intercept term

\footnotetext{
${ }^{6}$ Arithmetic mean is more appropriate than geometric mean because it gives a fairer result than the geometric mean. For example, if a dimension consists of three indicators of which one of the indicators has zero value, the end result of the geometric mean is zero although the other two ratios have good values. This condition does not happen in the arithmetic mean.
} 
$\beta_{\mathrm{i}}=$ regression coefficient

Pop $=$ population

$\mathrm{AP}=$ age profile

$W C=$ wealth of community

$\mathrm{PD}=$ population density

CSG $=$ cost of services and goods

$\mathrm{FE}=$ financial efficiency

$\mathrm{RB}=$ revenue base

$\boldsymbol{\varepsilon}=$ residuals terms.

This stage ends up by testing assumptions underlying multiple regression model.

\section{Result and Discussion}

\section{Developing Financial Condition Index (Dependent Variable)}

The result of the best 10 and the worst 10 of financial condition indexes of district LGs can be seen in Table 2. The process of developing the index and the complete list of the financial condition index will be provided upon request.

\section{Analyzing Factors Affecting the Financial Conditions}

The following sections discuss the results of the multiple regression analysis. There are three main results that will be analyzed: model summary; F-test; and significance testing. As in Dennis's (2004) study, this study uses a 10 percent level of statistical significance because of the exploratory nature of this study and its potential impact on future research about the emerging study of the financial condition of local government, especially in Indonesia. Table 3 provides information about the results of multiple regression analysis.

From the model summary presented in Table 3 , the adjusted $R$ square is 0.389 , which can be interpreted as the seven explanatory variables together in the model explained $38.9 \%$ percent of the variation in the financial condition of local government. This fact suggests that the financial condition of local government is a complex phenomenon as the variables used in the current study only explains about $38.9 \%$. More than $60 \%$ of the variation in the financial condition index is explained by unknown factors.

The F-test is used to test the significance of the regression model as a whole. The results of the F-test are shown in the ANOVA table. The $F$ value is 8.448 and the significant $F$ is 0.000 , smaller than 0.05 . As a consequence, we reject the null hypothesis of no linear relationship. Therefore it can be concluded that the regression model as a whole is significant at the 0.000 level. 
Ritonga, Clark \& Wickremasinghe

Factors Affecting Financial Condition of Local Government in Indonesia

Table 2 Dimension Indexes and Financial Condition Indexes of District Local Governments for Fiscal Year 2010

\begin{tabular}{|c|c|c|c|c|c|c|c|c|}
\hline Rank & District Local Government & FII & STSI & BSI & LTSI & SLSI & $\mathrm{FFI}$ & $\mathrm{FCl}$ \\
\hline 1 & Kabupaten Bekasi & 0.81 & 1.00 & 0.83 & 0.83 & 0.11 & 0.99 & 0.76 \\
\hline 2 & Kabupaten Sampang & 0.19 & 0.94 & 0.67 & 0.92 & 0.72 & 0.79 & 0.71 \\
\hline 3 & Kabupaten Demak & 0.40 & 0.93 & 0.60 & 0.87 & 0.42 & 0.96 & 0.70 \\
\hline 4 & Kabupaten Sidoarjo & 1.00 & 0.11 & 0.75 & 0.70 & 0.69 & 0.33 & 0.60 \\
\hline 5 & Kabupaten Bogor & 0.82 & 0.21 & 0.62 & 0.75 & 0.48 & 0.59 & 0.58 \\
\hline 6 & Kabupaten Jepara & 0.57 & 0.09 & 0.52 & 0.73 & 0.74 & 0.51 & 0.52 \\
\hline 7 & Kabupaten Tangerang & 0.97 & 0.11 & 0.57 & 0.65 & 0.19 & 0.54 & 0.50 \\
\hline 8 & Kabupaten Banjarnegara & 0.44 & 0.20 & 0.42 & 0.77 & 0.81 & 0.38 & 0.50 \\
\hline 9 & Kabupaten Jombang & 0.64 & 0.09 & 0.43 & 0.70 & 0.64 & 0.52 & 0.50 \\
\hline 10 & Kabupaten Bangkalan & 0.23 & 0.17 & 0.83 & 0.63 & 0.57 & 0.54 & 0.49 \\
\hline$\ldots$ & $\ldots$ & $\ldots$ & $\ldots$ & $\ldots$ & $\ldots$ & $\ldots$ & $\ldots$ & $\ldots$ \\
\hline$\ldots$ & $\ldots$ & $\ldots$ & $\ldots$ & $\ldots$ & $\ldots$ & $\ldots$ & $\ldots$ & $\ldots$ \\
\hline$\ldots$ & $\ldots$ & $\ldots$ & $\ldots$ & $\ldots$ & $\ldots$ & $\ldots$ & $\ldots$ & $\ldots$ \\
\hline 74 & Kabupaten Semarang & 0.68 & 0.12 & 0.33 & 0.36 & 0.07 & 0.19 & 0.29 \\
\hline 75 & Kabupaten Tasikmalaya & 0.08 & 0.07 & 0.32 & 0.66 & 0.24 & 0.36 & 0.29 \\
\hline 76 & Kabupaten Pekalongan & 0.54 & 0.08 & 0.24 & 0.30 & 0.44 & 0.11 & 0.28 \\
\hline 77 & Kabuapten Kediri & 0.37 & 0.12 & 0.58 & 0.19 & 0.33 & 0.12 & 0.28 \\
\hline 78 & Kabupaten Pemalang & 0.50 & 0.12 & 0.28 & 0.26 & 0.44 & 0.09 & 0.28 \\
\hline 79 & Kabupaten Purwakarta & 0.53 & 0.07 & 0.32 & 0.22 & 0.47 & 0.08 & 0.28 \\
\hline 80 & Kabupaten Sumedang & 0.59 & 0.00 & 0.22 & 0.23 & 0.51 & 0.04 & 0.26 \\
\hline 81 & Kabupaten Grobogan & 0.51 & 0.03 & 0.45 & 0.18 & 0.35 & 0.02 & 0.26 \\
\hline 82 & Kabupaten Ngawi & 0.00 & 0.18 & 0.20 & 0.35 & 0.63 & 0.17 & 0.25 \\
\hline 83 & Kabupaten Garut & 0.37 & 0.07 & 0.31 & 0.20 & 0.19 & 0.12 & 0.21 \\
\hline
\end{tabular}

Note: FII = Financial Independence Index; STSI = Short Term Solvency Index; BSI = Budgetary Solvency Index; LTSI = Long Term Solvency Index; SLSI = Service Level Solvency Index; FFI = Financial Flexibility Index; $\mathrm{FCl}=$ Financial Condition Index

The t-test is used to test the significance of individual coefficients. Table 3 reports that four variables (population, revenue-base, financial efficiency, and cost of production) are significant in explaining the financial condition because their significant values are less than 0.1 . However, population density, a wealth of community, and age profile are not statistically significant in predicting the financial condition of local governments.

All findings regarding directions of associations between financial condition and factors influencing it are in line with the hypotheses although three variables are not significant (wealth of community, age profile, and population density). These findings suggest that this study provides further evidence to explain the variability of the financial condition of LG under the laws of demand and supply.

Table 3 also shows that the variable for financial efficiency with $t$ value of 4.813 is the most important variable affecting the financial condition of $L G$ followed by the variables of revenue-base ( $t$ value $=2.663$ ), population ( $t$ value $=-2.239$ ), and cost of services and goods ( $t$ value $=-1.771$ ) consecutively. The information of the importance of variables could be used by LGs to set priorities for policies in order to improve the financial condition. 
Ritonga, Clark \& Wickremasinghe

Factors Affecting Financial Condition of Local Government in Indonesia

Table 3 Results of Multiple Regression Analysis

\begin{tabular}{|c|c|c|c|c|c|}
\hline & & lodel Sum & ary & & \\
\hline $\mathrm{R}$ & R Square & $\begin{array}{l}\text { Adjusted } \\
\text { R-Square }\end{array}$ & $\begin{array}{l}\text { Std. Error of } \\
\text { the Estimate }\end{array}$ & \multicolumn{2}{|c|}{ Durbin-Watson } \\
\hline $0.664(\mathrm{a})$ & 0.441 & 0.389 & 0.07807 & \multicolumn{2}{|c|}{2.275} \\
\hline \multicolumn{6}{|c|}{ ANOVA $^{a}$} \\
\hline & $\begin{array}{l}\text { Sum of } \\
\text { squares }\end{array}$ & Df & Mean Square & $F$ & Sig. \\
\hline Regression & 0.360 & 7 & 0.051 & 8.448 & $0.000^{\mathrm{t}}$ \\
\hline Residual & 0.457 & 75 & 0.006 & & \\
\hline Total & 0.818 & 82 & & & \\
\hline \multicolumn{6}{|c|}{ Coefficients $^{a}$} \\
\hline \multirow{2}{*}{ Variable } & \multicolumn{2}{|c|}{$\begin{array}{l}\text { Unstandardised } \\
\text { coefficients }\end{array}$} & $\begin{array}{l}\text { Standardise } \\
d\end{array}$ & \multirow{2}{*}{$\mathrm{t}$} & \multirow{2}{*}{ Sig. } \\
\hline & B & $\begin{array}{l}\text { Std. } \\
\text { error }\end{array}$ & Beta & & \\
\hline population size & $-4.89 \mathrm{E}-08$ & 0.000 & -0.333 & -2.239 & 0.028 \\
\hline revenue base & $5.184 \mathrm{E}-15$ & 0.000 & 0.409 & 2.663 & 0.009 \\
\hline $\begin{array}{l}\text { population } \\
\text { density }\end{array}$ & $2.048 \mathrm{E}-05$ & 0.000 & 0.106 & 0.962 & 0.339 \\
\hline cost of goods sold & $-1.62 \mathrm{E}-07$ & 0.000 & -0.217 & -1.771 & 0.081 \\
\hline $\begin{array}{l}\text { financial } \\
\text { efficiency }\end{array}$ & 0.356 & 0.074 & 0.661 & 4.813 & 0.000 \\
\hline age profile & -0.280 & 0.533 & -0.061 & -0.525 & 0.601 \\
\hline $\begin{array}{l}\text { community } \\
\text { wealth }\end{array}$ & -0.003 & 0.002 & -0.153 & -1.480 & 0.143 \\
\hline
\end{tabular}

a. Dependent variable: financial condition index

b. Predictors: (constant), community wealth, age profile, population size, population density, cost of goods sold, financial efficiency, revenue base

\section{Tests on Regression Assumptions}

A multiple regression model can be claimed as a good model if it fulfills the criteria of BLUE (Best Linear Unbiased Estimator) (Gujarati, 2003). The BLUE criteria can be achieved through the fulfillment of regression assumptions. Tests on regression assumptions are important because if such assumptions are not met the results and interpretation of regression analysis could be misleading. Osborne and Waters (2002) argue that when assumptions have not met the results may not be trustworthy, resulting in type I or type II error. This study tests five assumptions of multiple regression analysis: normality of residuals, homoscedasticity of residuals, multicollinearity, autocorrelation and linearity between a dependent variable and independent variables. To test each of the assumptions, this study uses more than one test in order to improve the robustness of results. 
Ritonga, Clark \& Wickremasinghe

Factors Affecting Financial Condition of Local Government in Indonesia

This study utilizes a graphical method and Shapiro-Wilk's $W$ test to assess the normality of the residuals because the sample is less than 2,000 (Garson, 2012). This study utilizes the graphical method, standard deviation comparison method, Durbin-Watson test method, and Ramseys RESET test to test the linearity of the model developed. It uses a graphical method, Spearman's Rank Correlation Test and Koenker-Bassett test to assess the homoscedasticity assumption. It uses the Durbin-Watson test to assess autocorrelation; and uses both Variance Inflation Factor (VIF) and the Tolerance to check whether multicollinearity exists.

The results show that all assumptions are not violated by this model. Therefore, the regression model in this study can be claimed to be a good model because it fulfills the criteria of BLUE (Best Linear Unbiased Estimator). The results of tests on regression assumptions are available upon request.

\section{Discussion}

In this part, authors focus discussion on factors that are not significant, which are community age profile, wealth of community, Population density. Authors will provide reasons why those factors are not held as proposed in developing hypotheses. Significant factors (i.e., Population size, revenue base, financial efficiency, cost of production of services and products) are not discussed because authors believe that arguments provided in developing hypotheses hold.

\section{Age Profile of Community}

This study fails to support hypothesis $\mathrm{H} 2$. This implies that the age profile of the community does not significantly impact LG financial condition. This finding does not support arguments proposed by Nollenbergeret al. (2003) and Berne and Schramm (1986) who argued that community tastes and needs as reflected in the age profile of community are inversely related with LG financial condition. They argued that the age profile helps to measure the level of current and future needs and the level of liabilities in the community.

The possible explanation of the insignificant relationship between age profile and LG financial condition is as follows. The insignificant relationship could indicate that LGs do not satisfy the need of their communities especially for community groups with people under the age of 18 years old and community groups with people over 60 years old. On the other hand, these non-working community groups need more certain type of facilities such as schools, parks, and recreation, nursing homes that are not needed by a group of the working community. Because LGs do not fulfill their communities' needs (i.e., by providing more services and goods), this condition will not result in significant additional expenditures of LGs. In turn, LG total expenditure would not increase significantly, and the per capita expenditure would not increase significantly, as well. As a result, there is no significant variation of LG financial condition between LG with a smaller number of non-working group and $L G$ with bigger number of non-working group. 
Ritonga, Clark \& Wickremasinghe

Factors Affecting Financial Condition of Local Government in Indonesia

The implication of the explanation above is that the central government has to evaluate whether the LGs have been applying the minimum services standards to the community groups with people under the age of 18 years old and community groups with people over 60 years old. As required by Government Regulation Number 65 the Year 2005 regarding minimum services standards, LGs have to deliver services at minimum services standards to the community and incorporating the minimum service standards that have been set by the central government to be one reference for LG planning and budgeting.

\section{Community Wealth}

From Table 6 above it can be seen that hypothesis $\mathrm{H} 3$ is rejected in this study. This suggests that the level of wealth of the community does not influence LG financial condition. This finding is not in line with previous studies which found a negative relationship between the wealth of community and LG financial condition (Ohls and Wales, 1972; Borcherding, 1985; Wang et al., 2007; Douglas andGaddie, 2002; Wolkoff, 1987).

The possible explanation of the insignificant relationship between age profile and LG financial condition is as follows. An increase in the level of income would not increase the demand for services or goods provided by the LG. This situation occurs because services or goods provided by LGs are perceived by the community as inferior products. "Inferior" here does not mean "bad", but indicates a product which is perceived to have less quality and to be less distinctive compared to services and products provided by private organizations.

Another possible explanation is that the handling process (such as punctuality, friendliness) of services and goods provided by LG officers is perceived as not good, although the services and goods provided are superior products. As a result, some of the community will switch to services and products provided by private organizations. Therefore, the demand curve of services and goods provided by LG would not shift to the right significantly. In turn, the total expenditure would not increase significantly, and LG per capita expenditure would not increase significantly, as well. As a result, there is no significant variation of LG financial condition between LG with lower community wealth and LG with higher community wealth.

The implication of the explanation above is that LGs have to improve the quality of services and goods delivered to the community. Also, the quality of the handling process of the services and goods must be improved as well. In turn, the community will have a good perception of the services and goods provided by LG.

\section{Population Density}

Table 6 shows that this study does not support hypothesis H4. This suggests that population density does not influence LG financial condition. This finding is not consistent with the findings of Borcherding and Deacon (1972); Downing (1973); Ladd (1992); and Carmeli (2008). They found that population density is inversely related to 
per capita expenditure.

The possible reason to explain the insignificant relationship between population density and the financial condition of $L G$ is as follows. The increasing population density would not result in the significant decrease in the cost per capita of delivering services and goods because there is significant inefficiency in delivering services and goods by LG. This condition happens because of the very high portion of employee expenditures as part of operational expenditures. It should be noted that employee expenditures are fixed expenditures. The composition of employee expenditures to total expenditures for the fiscal year 2011 was more than 50\% in 294 LGs in Indonesia (Harian Kompas, 25 August 2011, p.1). The impact of the inefficiency caused by the high portion of employee expenditures is bigger than the impact of the efficiency caused by the population density. With such condition, the provision of public services such as street maintenance, the number of schools or health centers by the LG with a compact boundary and a high population density will not be less costly per capita significantly compared to an LG with less compact boundary and less population density. The implication of the explanation above is that LGs have to improve their operational efficiency, especially employee expenditures, in delivering services and goods to the community.

\section{Practical Implications}

Based on these results, the study brings a message to LGs which is to give more attention to variables of financial efficiency if they want to improve their financial condition. The LG should put the variable as the priority to be maintained because the variable is the variable that can be controlled by the LG. Besides that, looking at the coefficients of each variable that significantly influence financial condition, the variable of financial efficiency (i.e., 0.376) has the biggest influence on the LG financial condition. This condition means that the increase of financial efficiency by one unit will lead to the improvement of the financial condition index by 0.376 , assuming that other variables are held fixed.

To increase financial efficiency, LGs should evaluate their operational expenditures. The largest component of operational expenditures is employee expenditures. In Indonesia, the composition of employee expenditures to total expenditures for the fiscal year 2011 is more than $50 \%$ in 294 LGs in Indonesia. There are several LGs which allocated more than $70 \%$ of their budget for employee expenditures (Harian Kompas, 25 August 2011, p.1). Thus, LGs should evaluate employee expenditure whenever they want to increase financial efficiency. LGs have to assure that they have an optimum number of employees at the appropriate level of salary. If an LG has too many employees, the LG can transfer the excess employees to another LG where there is a shortage of employees. Another way to control the employee expenditures is by establishing a moratorium of employee recruitment. In addition, LGs could implement several strategies in order to reduce employee expenditure such as reduce overtime, lay off personnel, implement early retirement, and reduce employee compensation levels. Such strategies have been taken by LGs in the United States (Pammer and Morgan, 1988). 
Furthermore, Hyman (1990) argued that innovations in budgeting policies could reduce the costs of supplying LG-provided services. These policies will push LG top executives to choose the minimum cost alternatives. For example, these alternatives include transferring the responsibility for supplying services and goods to private enterprises if they can supply these services and goods more efficiently. Hyman's argument is supported by Morgan and Pammer's (1988) findings. In their study, they found that LGs in the United States used several strategies to improve financial efficiency by implementing better management, adopting labour saving techniques, contracting out services with the private sector, implementing joint purchasing agreements, shifting responsibilities to other units of government, and contracting out services with other units of government. Honadle et al. (2004) also offered strategies for LGs to be more efficient which include consolidating departments, combining facilities, closing building, eliminating units of LGs. These strategies could reduce overhead expenditures to achieve economies of scale.

The next priority to improve LG financial condition is the variable of cost of services and goods because this variable can also be directly controlled by LG although it is the least important variable when considered from the $t$ - value aspect (i.e., 2.086). LG should be careful when determining the regional minimum wage because this cost is an important component of the total cost of services and goods. On one side, it is a popular policy for the local leader to set the minimum of regional wage at a higher level, but on the other side it has a negative association with the financial condition of $L G$.

Regarding variables of population and revenue-base, which cannot be controlled directly by LG, LG should create appropriate policies regarding these variables to improve the financial condition. For the variable of the population which has a negative association with the financial condition, LG should control the growth of population. For example, LGs should encourage the community to follow family planning program. In addition, Honadle et al. (2004) offered other strategies such as making it difficult for people who would have a higher demand for LG-provided services to move into the jurisdiction or making it difficult for them to remain in the jurisdiction.

Regarding revenue-base, an LG should create a warm climate for economic growth. For example, LGs could provide legal certainty and incentives such as tax reduction for investors. Other strategies are creating jobs, expanding sales by local business, and making strategic investments of their resources (Honadle et al., 2003).

\section{Conclusion}

This study aimed to determine the factors affecting the financial conditions of LGs in Indonesia. This study finds that the significant factors affecting financial conditions of LGs are population, cost of production of services and goods, financial efficiency, and revenue-base. The insignificant factors are population density, the age profile of community, and wealth of the community. 
Findings of this study are useful for the central government, LG executives and legislators in Indonesia to make effective policies pertaining to the financial conditions of LG. Consequently, the quality of decision-making regarding LG financial management would be improved. For Indonesian scholars, this study represents the first attempt to assess the financial conditions of LGs in Indonesia.

There may be other factors that influence the financial conditions of LGs, but these factors are not addressed in this study. Based on the law of supply, technology is known as one factor that influences the number of products and services produced by an organization. This study does not examine the impact of this variable on financial conditions of LGs because there was no data available about the level of technology utilization in LGs in Indonesia when this study was undertaken. Another factor that could influence the financial conditions of LGs is the geographic location of a local government (Casal and Gomez, 2011). Another limitation of this study could be a relatively small number of the sample that could reduce the universality of the results of this study.

\section{References}

Altman, E. I. (1968). Financial ratios, discriminant analysis and the prediction of corporate bankruptcy. The Journal of finance, 23(4), 589-609. https://doi.org/10.2307/2978933

Boumol, W. J. (1967). Macroeconomics of unbalanced growth: the anatomy of urban crisis. The American economic review, 57, 415-426.

Beaver, W. H. (1966). Financial Ratios As Predictors of Failure. Journal of Accounting Research, 4, 71-111. https://doi.org/10.2307/2490171

Beck, M. (1982). Toward a theory of public sector growth. Public Finance, 37(2), 163-77. Retrieved from https://ideas.repec.org/a/pfi/pubfin/v37y1982i2p163-77.html

Berne, R. and Schramm, R. (1986). The financial analysis of governments, Prentice-Hall.

Borcherding, T. E. (1985). The causes of government expenditure growth: A survey of the US evidence. Journal of Public Economics, 28(3), 359-382. https://doi.org/10.1016/00472727(85) 90065-9

Borcherding, T. E., \& Deacon, R. T. (1972). The demand for the services of non-federal governments. The American economic review, 62(5), 891-901. Retrieved from http://www.socsci.uci.edu/ jkbrueck/course $\% 20$ readings/Econ $\% 20272 \mathrm{~B} \% 20$ readin gs/borcherding-deacon.pdf

Bradford, D. F., Malt, R. A., \& Oates, W. E. (1969). The rising cost of local public services: Some evidence and reflections. National Tax Journal, 22(2), 185-202. Retrieved from https://pdfs.semanticscholar.org/cfc8/49137f5c0720af0f6eb13d249ceacc7c432d.pdf

Carmeli, A. (2008). The fiscal distress of local governments in Israel: Sources and coping strategies. Administration \& Society, 39(8), 984-1007. https://doi.org/10.1177/0095399707309358

Carmeli, A., \& Cohen, A. (2001). The financial crisis of the local authorities in Israel: A resource-based analysis. Public Administration, 79(4), 893-913. https://doi.org/10.1111/1467-9299.00285

Casal, R. C., \& Gómez, E. B. (2011). Impact of size and geographic location on the financial condition of Spanish municipalities. Transylvanian Review of Administrative Sciences, 7(34), 
22-39. Retrieved from

http://www.rtsa.ro/tras/index.php/tras/article/viewFile/297/290

Clark, T. N. (1994). Municipal fiscal strain: Indicators and causes. Government Finance Review, 10, 27-27.

CICA (1997). Indicators of Government Financial Condition. Toronto: Canadian Institute of Chartered Accountants.

Deacon, R. T. (1978). A demand model for the local public sector. The Review of Economics and Statistics, 60(2), 184-192. https://doi.org/10.2307/1924971

Dennis, L. M. (2004). Determinants of Financial Condition: A Study of US Cities. Florida: University of Central Florida Orlando.

Douglas, J. W., \& Gaddie, R. K. (2002). State rainy day funds and fiscal crises: Rainy day funds and the 1990-1991 recession revisited. Public Budgeting \& Finance, 22(1), 19-30. https://doi.org/10.1111/1540-5850.00063

Downing, P. B. (1973). User charges and the development of urban land. National Tax Journal, 26, 631-637.

Groves, S. M., Godsey, W. M., \& Shulman, M. A. (1981). Financial indicators for local government. Public Budgeting \& Finance, 1(2), 5-19. https://doi.org/10.1111/1540$\underline{5850.00511}$

Gujarati, D. N. (2003). Basic econometrics, 4th ed. U.S.A: McGraw Hill.

Hendrick, R. (2004). Assessing and measuring the fiscal heath of local governments: Focus on Chicago suburban municipalities. Urban Affairs Review, 40(1), 78-114. https://doi.org/10.1177/1078087404268076

Honadle, B. W. (2003). The states' role in US local government fiscal crises: A theoretical model and results of a national survey. International Journal of Public Administration, 26(13), 1431-1472. https://doi.org/10.1081/pad-120024405

Honadle, B. W., Costa, J. M., \& Cigler, B. A. (2004). Fiscal Health for Local Governments: An Introduction to Concepts. Practical Analisys and Strategies, San Diego California USA.

Hyman (1990). Public finance. New York: Harcourt Brace College Publishers.

Jin, T., \& Zhang, J. (2011). Effect of local government expenditure on the ratio of output to capital: Evidence from panel data at China's provincial level. Frontiers of Economics in China, 6(2), 249. https://doi.org/10.1007/s11459-011-0131-7

Jones, S., \& Walker, R. G. (2007). Explanators of local government distress. Abacus, 43(3), 396-418. https://doi.org/10.1111/j.1467-6281.2007.00238.x

Kamnikar, J. A., Kamnikar, E. G., \& Deal, K. H. (2006). Assessing a state's financial condition. The Journal of Government Financial Management, 55(3), 30.

Kloha, P., Weissert, C. S., \& Kleine, R. (2005). Developing and testing a composite model to predict local fiscal distress. Public Administration Review, 65(3), 313-323. https://doi.org/10.1111/i.1540-6210.2005.00456.x

Kloha, P., Weissert, C. S. and Kleine, R. (2005b). Someone to Watch Over me. The American Review of Public Administration, 35(3), 236-255. https://doi.org/10.1177/0275074005277435

Ladd, H. F. (1992). Population growth, density and the costs of providing public services. Urban Studies, 29(2), 273-295. https://doi.org/10.1080/00420989220080321

Mankiw, N. G., Stonecash, R., Gans, J. and King, S. (1999). Principles of Macroeconomics, Australia: Harcourt Australia.

Morgan, D. R., \& Pammer Jr, W. J. (1988). Coping with fiscal stress: Predicting the use of financial management practices among US cities. Urban Affairs Quarterly, 24(1), 69-86. https://doi.org/10.1177/004208168802400105 
Nollenberger, K., Groves, S. M. and Valente, M. G. (2003). Evaluating financial condition: A handbook for local government. Washington, DC, International City/County Managers Association.

Ohls, J. C. and Wales, T. J. (1972). Supply and demand for state and local services. The Review of Economics and Statistics, 54(1), 424-430. https://doi.org/10.2307/1924569

Osborne, J., \& Waters, E. (2002). Four assumptions of multiple regression that researchers should always test. Practical assessment, research \& evaluation, 8(2), 1-9. Retrieved from https://www.researchgate.net/profile/Jason Osborne2/publication/234616195 Fou r Assumptions of Multiple Regression That Researchers Should Always Test/lin ks/59302555aca272fc55e144da/Four-Assumptions-of-Multiple-Regression-ThatResearchers-Should-Always-Test.pdf

Pammer, W. J. (1990). Managing fiscal strain in major American cities: Understanding retrenchment in the public sector. New York: Greenwood Press.

Ritonga, I., Clark, C. and Wickremasinghe, G. (2012). Developing a Measure of Local Government Financial Condition. The 13th International Annual Conference Asian Academic Accounting Association.Kyoto, Japan, 9-12 ${ }^{\text {th }}$, November 2012.

Ritonga, I. T., Clark, C., \& Wickremasinghe, G. (2012). Assessing financial condition of local government in Indonesia: an exploration. Public and Municipal Finance, 1(2), 37-50. Retrieved from https://businessperspectives.org/images/pdf/applications/publishing/templates/arti cle/assets/4282/pmf 201202 Ritonga.pdf

Rivenbark, W. C., Roenigk, D. J. and Allison, G. S. 2009. Communicating Financial Condition to Elected Officials in Local Government. Popular Government, Fall 2009, 413.

Rivenbark, W. C., \& Roenigk, D. J. (2011). Implementation of financial condition analysis in local government. Public Administration Quarterly, 241-267.

Rivenbark, W. C., Roenigk, D. J., \& Allison, G. S. (2010). Conceptualizing financial condition in local government. Journal of Public Budgeting, Accounting \& Financial Management, 22(2), 149-177.

Rubin, I. 1(982). Running in the red: The political dynamics of urban fiscal stress. New York: State University of New York (SUNY) Press.

Rubinfeld, D. L. (2000). Reference guide on multiple regression. Reference manual on scientific evidence, 179, 425-469. Retrieved from https://pdfs.semanticscholar.org/6d06/8ed84de4c4daeb28734632e23311958eecf6.pd $\underline{f}$

Wang, X., Dennis, L., \& Tu, Y. S. (2007). Measuring financial condition: A study of US states. Public Budgeting \& Finance, 27(2), 1-21. https://doi.org/10.1111/j.1540$\underline{5850.2007 .00872 . x}$

Wolkoff, M. (1987). An evaluation of municipal rainy day funds. Public Budgeting \& Finance, 7(2), 52-63. https://doi.org/10.1111/1540-5850.00743

Zafra-Gómez, J. L., Lopez-Hernandez, A. M., \& Hernández-Bastida, A. (2009). Developing a model to measure financial condition in local government: Evaluating service quality and minimizing the effects of the socioeconomic environment: An application to Spanish municipalities. The American Review of Public Administration, 39(4), 425-449. https://doi.org/10.1177/0275074008320710

\section{Regulation:}

Republic of Indonesia. (2003). State Finance Act 2003 No. 17 (Undang-Undang Nomor 17 Tabun 2003 tentang Keuangan Negara). 


\section{Ritonga, Clark \& Wickremasinghe}

Factors Affecting Financial Condition of Local Government in Indonesia

Republic of Indonesia. (2004). Local Government Amendment Act 2004 No. 32 (Undangundang Nomor 32 Tabun 2004 tentang Pemerintahan Daerab).

Republic of Indonesia. (2004). Fiscal Balance between Central and Local Government Amendment act 2004 No. 33 (Undang-undang Nomor 33 Tabun 2004 tentang Perimbangan Keuangan antara Pemerintah Pusat dan Pemerintahan Daerah).

\section{Article in Website:}

Garson, GD. 2012. Statnotes: Topics in multivariate analysis [Online]. Available at: http://faculty.chass.ncsu.edu/garson/PA765/statnote.htm 